\author{
ACTA MYCOLOGICA \\ Vol. 44 (1): 29-42 \\ 2009
}

\title{
New localities of Chamonixia caespitosa (hypogeous Boletaceae) in Central Europe
}

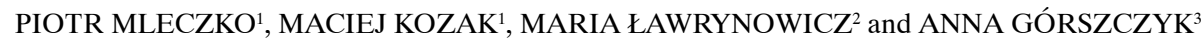

\author{
${ }^{1}$ Institute of Botany, Jagiellonian University, Lubicz 46 \\ PL-31-512 Kraków, ubmleczk@cyf-kr.edu.pl \\ ${ }^{2}$ Department of Mycology, University of Łódź \\ Banacha 12/16, PL-90-237 Łódź, miklaw@biol.uni.lodz.pl \\ ${ }^{3}$ Orzeszkowej 6, PL-32-640 Zator
}

Mleczko P., Kozak M., Ławrynowicz M., Górszczyk A.: New localities of Chamonixia caespitosa (hypogeous Boletaceae) in Central Europe. Acta Mycol. 44 (1): 29-42, 2009.

Chamonixia caespitosa Rolland, has been recently found in Poland for the first time after 1945. The basidiocarps, partially exposed from the humus layer, were found in two localities: in the spruce forest in the Polish Tatra Mts., at the elevation of $1540 \mathrm{~m}$ a.s.l., and in the mixed forest with spruce and fir in the Beskid Niski Mts. at the elevation of app. $400 \mathrm{~m}$ a.s.l. The description of the Polish specimens generally agrees with descriptions of the specimens found in other Central European countries. The roundish to tuberculate basidiocarps were characterized by the presence of highly reduced stipe, whitish colour of the peridium changing rapidly to blue after exposure to air, small, complete or incomplete columella and brown, spongy gleba. Typically 4-spored basidia were present which produced ellipsoid, brown spores with the ornamentation in the form of rough, interconnected ridges. Taxonomic position, ecology and chorology of the species, the ontogeny of basidiocarps and description of ectomycorrhizae are summarized in the paper.

Key words: hypogeous fungi, ectomycorrhizal fungi, Boletales, Tatra Mts., Beskid Niski Mts.

\section{INTRODUCTION}

Chamonixia caespitosa was found for the first time in 1898 in Chamonix (French Alps) by M.L. Rolland, who described it one year later as a new species and a new genus (Rolland 1899). German mycologist E. Soehner collected basidiocarps of this fungus in the Bavarian Alps and described the taxon independently as a new one in 1922, however, he placed the species in the genus Hymenogaster (as H. caerulescens). He did not change this opinion after reading Rolland's description but accepted Rolland's priority, and made a new combination: Hymenogaster caespitosus (Rolland) 
Soehner (Soehner 1949). Several studies, however, strongly supported Chamonixia as a separate genus and established its position within Boletales (see Discussion). Since its discovery Chamonixia caespitosa Rolland has been found in several European countries and also outside Europe.

The first Polish locality of Chamonixia was discovered in 1923 by Buchs in Karkonosze range (German name: Riesengebirge), Sudety Mountains, above Karpacz Górny town (German name: Brückenberg), in that time within Germany (Soehner 1949).

Recently after 85 years the species has been found in Poland in two localities. These are the first contemporary collections of this species, and the first records in the Polish Carpathians. In the article the localities of Chamonixia caespitosa with description of macroscopic and microscopic features of the basidiocarps are presented. The authors discuss taxonomic position, ecology and chorology of this species, the ontogeny of its basidiocarps and description of its ectomycorrhizae.

\section{METHODS}

Description of the basidiocarps was based on fresh and dry material. The measurements of microscopical features were taken on dry material mounted in $3 \% \mathrm{KOH}$. The information on the dimensions of spores and other structures are based on 25-30 measurements. Measurements of spores include spore ornamentation but excluded apiculus.

The specimens have been deposited in the Mycological Collection of the Institute of Botany Herbarium at the Jagiellonian University in Kraków (KRA-F 2008-3, 2009-1).

\section{RESULTS}

Chamonixia caespitosa Rolland, Bull. Soc. mycol. Fr. 15: 73-78, pl. 6/3. 1899.

Basidiocarps mostly single (not caespitose), in one case two young adhering basidiocarps with single stipe were found (on second locality), roundish and slightly flattened to irrergularely tuberculate, with well defined base formed as a short, tapered stalk, with some small rhizomorphs attached. Fruitbody surface slightly woolly, felty, cracked in places and exposing inner layers of the peridium, whitish to creme or ochraceous, when bruised rapidly changing colour becoming blue (Fig. 1), greenish to olive on drying (Fig. 2). Peridium (Fig. 3) in cross section 0.1-0.2 $\mathrm{mm}$ thick, separating from gleba. Whitish columella present, connected with a basal stalk, with context also turning blue after cutting. Columella either complete (basidiocarps from second locality) or triangle in section and not percurrent, but than it was found to continue as a thin layer of hyphae oriented to the site rather than to the top of the gleba (basidiocarps from the first locality). Gleba spongy, labyrinthine, with 
17

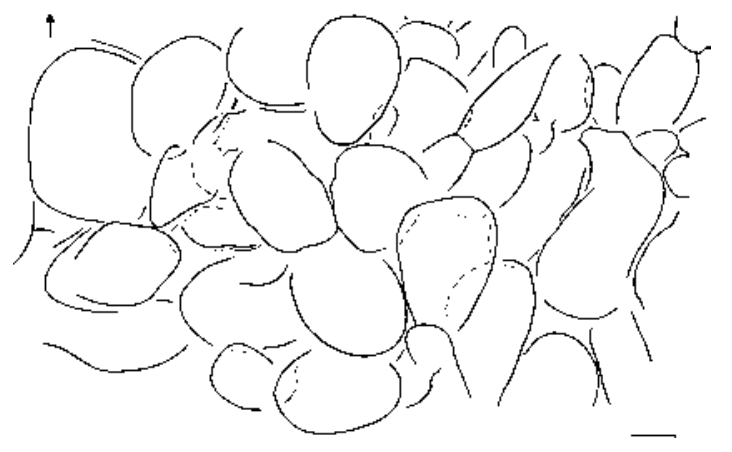

18

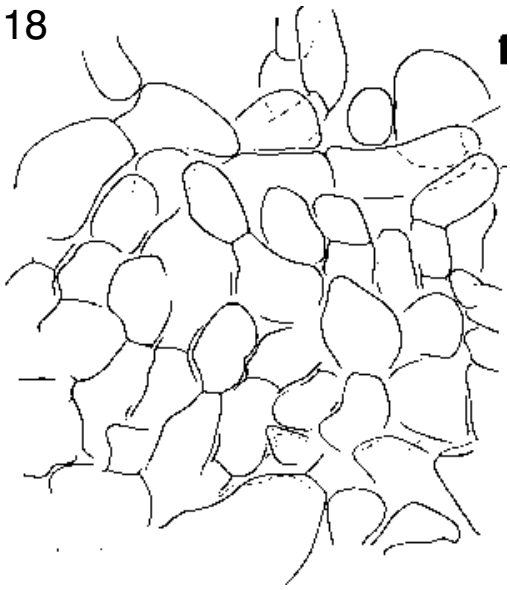

19
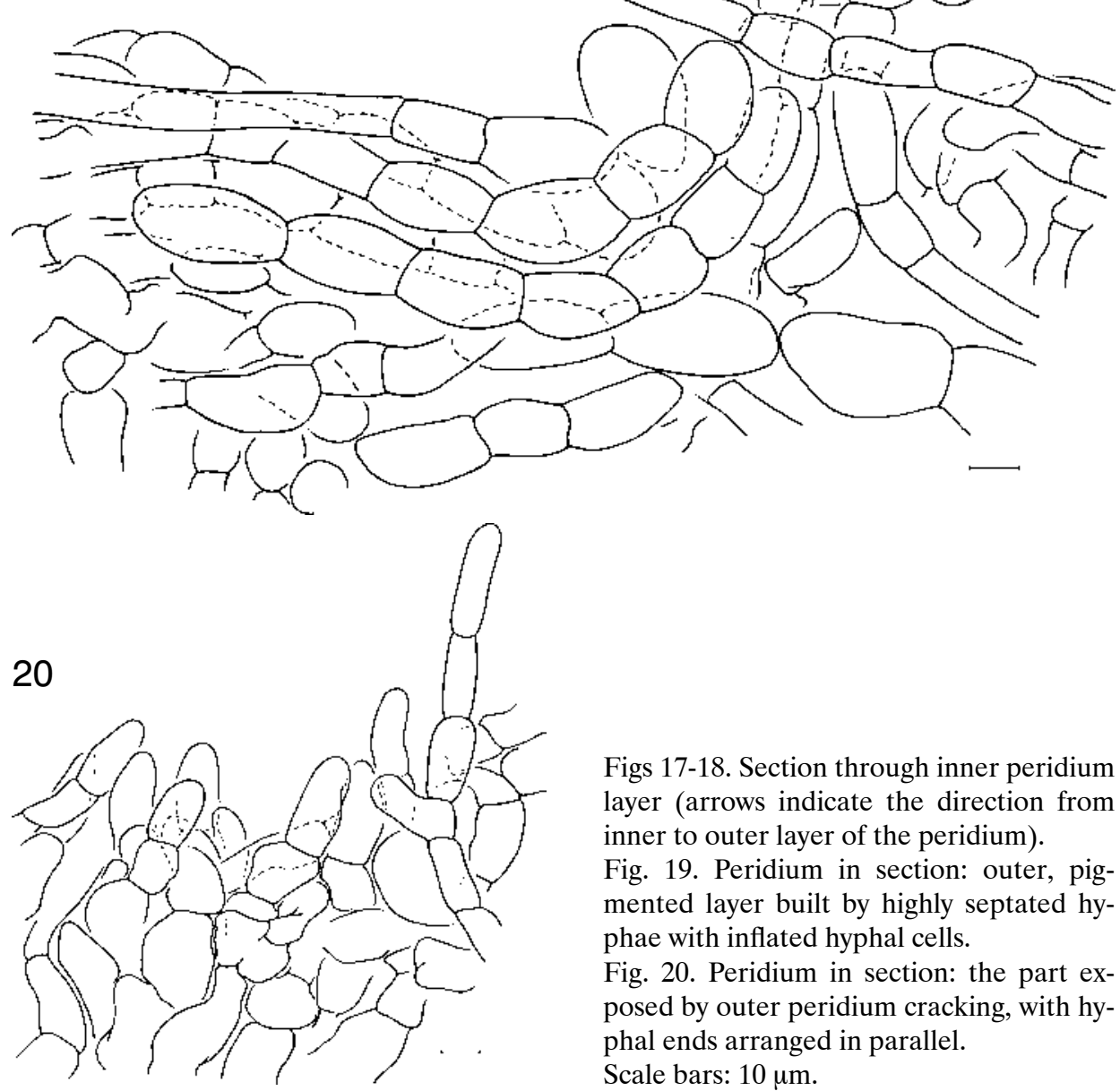

Figs 17-18. Section through inner peridium layer (arrows indicate the direction from inner to outer layer of the peridium).

Fig. 19. Peridium in section: outer, pigmented layer built by highly septated hyphae with inflated hyphal cells.

Fig. 20. Peridium in section: the part exposed by outer peridium cracking, with hyphal ends arranged in parallel.

Scale bars: $10 \mu \mathrm{m}$. 

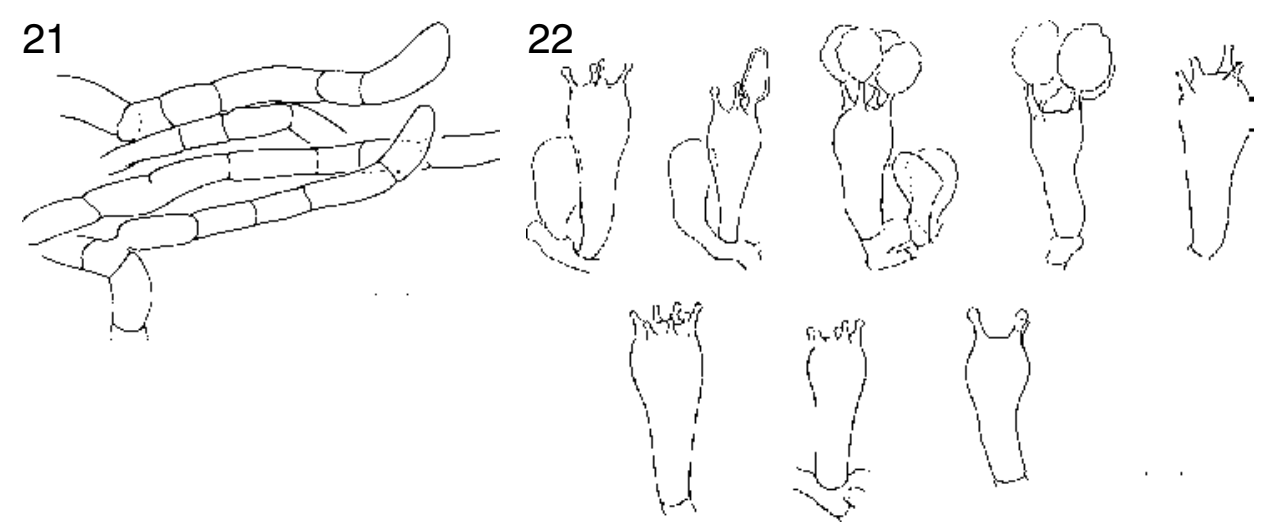

Fig. 21. Hyphae on the peridium surface, with not inflated hyphal cells.

Fig. 22. Basidia (note basidia with 5 and 7 sterigmata).

Fig. 23. Section through hymenium and subhymenium with basidia and sterile elements.

Scale bars: $10 \mu \mathrm{m}$.

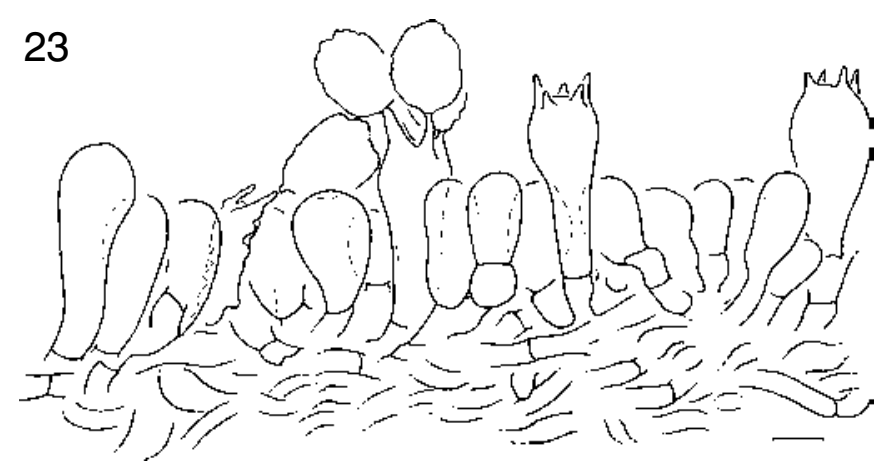

small empty interconnected and irregular veins, generally app. $0.5 \mathrm{~mm}$ in diam. (up to $1 \mathrm{~mm}$ max.), whitish to light greyish, partially blueing after cutting (especially near peridium), with brown hue due to the deposit of spores, then brown to brownish with a slight reddish or pinkish hue (Figs 3, 4).

Peridium double-layered, the inner layer (Figs 10,17, 18) pseudoparenchymatous (or nearly so) in section, build by app. roundish, ellipsoid or cuboid hyphal cells with hyaline walls; cells 10-43 (mean: 22.1) x 7-28 (mean: 14.4) $\mu \mathrm{m}$. The outer layer of the peridium (Figs 5-8 and 19-21) plectenchymatous, hyphae mostly perpendicular to the peridium surface but some of them appressed, hyphal cells short and mostly inflated, plasmatically and membranously yellowish in water and in $\mathrm{KOH}$, (9) 13-28 (45) (mean: 18.8) $\mu \mathrm{m}$ long and 7-13 (mean: 10.0) $\mu \mathrm{m}$ in diameter.

Basidia (Figs 11, 22, 23) mostly 4-spored (exceptionally basidia with 5 or 7 sterigmata were found, Fig. 22), thin-walled and hyaline, clavate, 37-45 (51) (mean: 42.7) $\mu \mathrm{m}$ long, 16-18.5 (20) (mean: 17.7) $\mu \mathrm{m}$ in diameter at the top and 8-10 (mean: 8.9) $\mu \mathrm{m}$ in diameter at the base.

Sterile elements thin-walled and hyaline (Figs 11, 23), broadly clavate to almost cylindrical, shorter than basidia, 20-34 (mean: 27.3) $\mu \mathrm{m}$ long and (5) 9-17 (mean: 11.7) $\mu \mathrm{m}$ in diameter (at the top). Cystidia and clamps absent.

Tramal hyphae (Figs 11, 23) clampless, thin-walled and mostly hyaline (rarely slightly yellowish), 3.5-7 (mean: 4.7) $\mu \mathrm{m}$ in diameter, growing app. parallely but sometimes irregularly distributed, hyphal walls not gelified but hyphae may be immersed 
in a matrix material in places. Trama (including subhymenium) not conspicuously developed, 25-50 (mean: 39.6) $\mu$ m thick.

Spores elongated, ellipsoid to broadly ellipsoid, tapering towards the base, 16-23 (mean: 19.6) $\mu \mathrm{m}$ long and 12.5-16 (mean: 14.0) $\mu \mathrm{m}$ in diameter (including ornamentation), with an apiculus (hilar appendage) centrally positioned, straight and truncate; spore surface rough and grainy (Figs 12-16), covered with conspicuous, interconnected, rarely single, ridges up to $5 \mu \mathrm{m}$ thick, which make the spores irregularly star-like in optical section; usually 4-6 (7) complete or partial, longitudinal ridges visible in side view, sometimes the ridges may be difficult to discern (see Fig. 15). The spore wall 1.5-3.5 $\mu \mathrm{m}$ thick (including ornamentation). The ornamentation of the top of the spore typically star-like, consisting of short lobes continuous with the ridges or independent of them (Figs 14, 16). Colour of mature spores yellow- to reddish-brown; young, immature spores hyaline then yellowish to yellowish-brown. The wall of young, immature spores slightly dextrinoid and strongly cyanophilous.

LocAlities. The fruitbodies were found in two localities in Southern Poland.

1. August 2008, the Western Tatra Mts., in the upper part of the Tomanowa valley (49 $\left.13^{\prime} 23^{\prime \prime} \mathrm{N}, 19^{\circ} 53^{\prime} 43^{\prime \prime} \mathrm{E}\right)$ exposed to the west, at the elevation of $1540 \mathrm{~m}$ a.s.l. The collection site is situated in the part of the Tatra Mts. with the limestone bedrock. Single basidiocarp was found in the montane old-growth spruce forest (association: Polysticho-Piceetum), on a gentle slope by the forest path, app. $0.5 \mathrm{~m}$ above the path's level. It was growing among spruce roots on the ground scarcely covered with mosses. The basidiocarp was partially exposed from the soil.

2. June 2009, Beskid Niski Mts., Pagorzyna (Pogorzyna) near Lipinki (49 41' 29'N, 21' 19' 16"E), app. 350-400 m a.s.l. Six basidiocarps were found in the mixed forest dominated by fir (Abies alba) and spruce (Picea excelsa), growing in soil covered with mosses, partially exposed from the substratum, on flat, damp ground, between two forest paths.

\section{DISCUSSION}

The genus Chamonixia comprises 9 species: Chamonixia albida (Massee \& Rodway) Y.S. Chang \& Kantvilas (syn. Gautieria albida, Hymenogaster albidus), Chamonixia bispora B.C. Zhang \& Y.N. Yu, Chamonixia brevicolumna A.H. Sm. \& Singer, Chamonixia caespitosa Rolland, Chamonixia caudata (Zeller \& C.W. Dodge) A.H. Sm. \& Singer (syn. Arcangeliella caudata), Chamonixia mucosa (Petri) Corner \& Hawker (syn. Gautieria mucosa, Hymenogaster mucosus), Chamonixia octorugosa Corner \& Hawker, Chamonixia pachydermis (Zeller \& C.W. Dodge) G.W. Beaton, Pegler \& T.W.K. Young (syn. Hymenogaster pachydermis, Hysterangium sclerodermum sensu Cunningham), Chamonixia vittatispora G.W. Beaton, Pegler \& T.W.K. Young (Corner, Hawker 1953; Smith, Singer 1959; Beaton, Pegler, Young 1985; Zhang, Yu 1989; Chang, Kantvilas 1993). The fruitbodies of most of the species turn blue after bruising. The species differ in: spore dimensions, spore morphology (number, size and form of ridges), presence of columella (present or absent), number of spores produced by basidia ( 2 or up to 4 ) or, rarely, cyanescent reaction (present or absent). 
According to Label (2006) Australian species of Chamonixia may represent a different taxon and perhaps deserve a new generic name.

Chamonixia caespitosa is characterized by the presence of (in most cases incomplete) columella, the spores with (6) 8 or more (up to 16) ribs on their surface, and by (generally) 4-spored basidia. However, the differences between the original description by Rolland and descriptions by other authors were realized (2-spored versus 4-spored basidia, caespitose versus mostly single basidiocarps, e.g. Kotlaba 1971) and it was suggested that perhaps Rollands species might represent a different taxon than the one described later by Soehner (1922) under the name Hymenogaster caerulescens. The problem has not been solved until today as the Rolland's type collection of Chamonixia caespitosa was not found (Capellano 1967).

The features of the specimens from the Polish Tatra Mts. and Beskid Niski Mts. generally agree with the descriptions given by other authors (e.g., Soehner 1922; Lange, Hawker 1951; Capellano 1967; Kotlaba 1971; Hagara 1985; Kers 1985; Breitenbach, Kränzlin 1986; Hæggström 1987; Montecchi, Sarasini 2000). Our fruitbodies were mostly single and not consisting of several basidiocarps joined by common stalk, as described for the type collection by Rolland. However, more complex basidiocarps were also found. Hagara (1985), Kers (1985) and Cheype (1990) reported fruitbodies consisting of two even or uneven parts growing from a common base (stalk). The dimensions of spores only slightly vary in different descriptions; more variable dimensions were detected among basidia (Tab. 1).

Table 1

Comaprison of the dimensions of basidiospores and basidia from different European collections (data in $\mu \mathrm{m}$ )

\begin{tabular}{|l|c|c|}
\hline \multicolumn{1}{|c|}{ Country } & Basidiospores & Basidia \\
\hline Czech Republic (Kotlaba 1971) & $16.7-20 \times 12.5-15.5$ & $37-41 \times 14.5-18$ \\
\hline Finland (Hæggström 1987) & $16-24 \times 10.5-15$ & - \\
\hline France (Capellano 1967; Cheype 1990) & $16-22 \times 12-15$ & $\begin{array}{c}30-35 \times 14-16 \\
45-55 \times 17-19\end{array}$ \\
\hline Germany (Soehner 1922; Groß et al. 1980) & $\begin{array}{c}17-22 \times 12-14(15) \\
\text { (some }>25 \text { or }<17 \\
\text { long) }\end{array}$ & $35-45 \times 15-20$ \\
\hline Italy (Montecchi, Sarasini 2000) & $13-28 \times 8-14$ & $35-55 \times 15-20$ \\
\hline Norway, Sweden (Kers 1985; Lange, Hawker 1951) & $\begin{array}{c}(16) 18-20 \times(13) 14- \\
15\end{array}$ & app. 36 $\times 18$ \\
& $\begin{array}{c}1 \text { (untypical: 25 } 2515, \\
18-20.5 \times 12.7-15.2\end{array}$ & \\
& $16-23 \times 12.5-16$ & $37-45(51) \times 16-18.5$ \\
& & $(20)$ \\
\hline Poland & $17-25 \times 11-15$ & $28-37 \times 15-17$ \\
\hline Slovakia (Hagara 1985) & $18-22 \times 13-15$ & $40-50 \times 15-20$ \\
\hline Switzerland (Breitenbach, Kränzlin 1986) & & \\
\hline
\end{tabular}

The description of trama elements as well as the structure of the peridium and dimensions of it's hyphae given by Kotlaba (1971) for Czech specimens, one of the closest localities to the Polish one (no such data for Slovak specimens) correspond well with our observations. However, Kotlaba did not mention a double-layered structure of the peridium, which in our specimen was evident not only in hyphal structure but also in colour (yellowish outer layer and hyaline inner one). This double-structure was, in turn, described in detail by e.g., Capellano (1967) who, however, found no trichodermal structure in the outermost layer described for the American 
species of Chamonixia (Smith, Singer 1959). Although such structure was also not observed in the Polish specimens, some appressed hyphae were found in the outer peridium and parallel arrangement of hyphal ends was seen in the places where peridium was cracked (see Figs 9 and 20). The hyphae forming septa of the gleba were mostly described as not gelified (e.g., Capellano 1967) but, at least partially, gelified

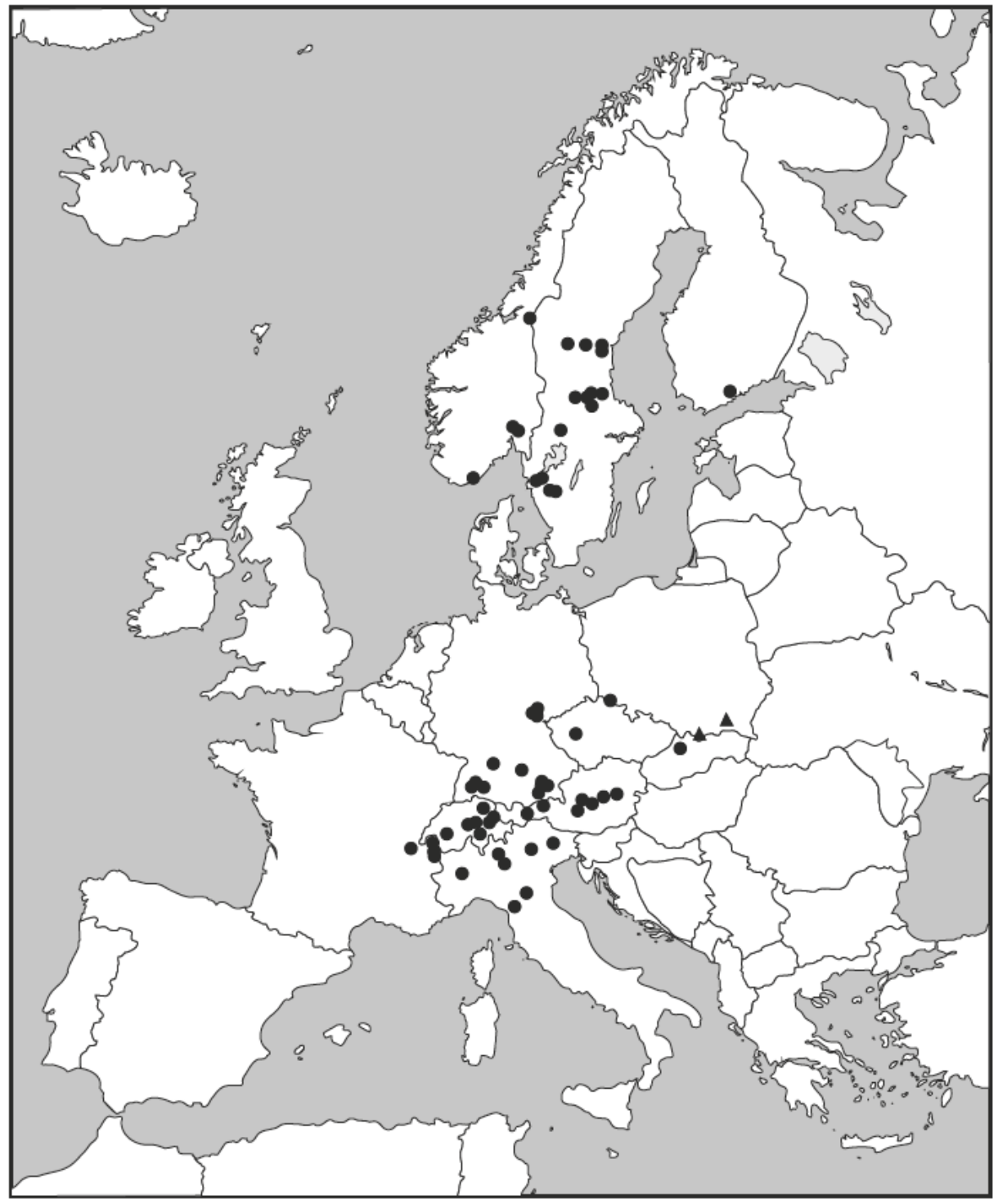

Fig. 24. Distribution map of Chamonixia caespitosa in Europe.

Remarks: in case of Austrian, Norwegian and Swiss localities, apart from printed data, the information from electronic distribution maps was used (Austrian Mycological Society 2008; Bendiksen, Molia 2009; Verbreitungsatlas der Pilze der Schweiz). Number of dots not necessarily reflects exact number of localities known (in case of Austria, Germany, Norway, Sweden, Switzerland). 
tramal hyphae were described by Lange and Hawker (1951), and American authors, and this was also found in case of the Polish specimens.

The species is known from Czech Republic (Kotlaba 1971), Slovakia (Hagara 1985), Austria (Groß 1974; Mader, Mader 1975), Germany (e.g., Soehner 1922, 1949; Groß 1974, 1975; Groß et al. 1980; Raidl 1999; Zureck et al. 1999), Finland (Hæggström 1987), Norway (Lange, Hawker 1951; Bohlin, Jeppson 1983), Sweden (Bohlin, Jeppson 1983; Kers 1985; Bohlin 2005, 2006; Bohlin, Bohlin 2005; Vesslén, Bengtson 2008), France (Rolland 1899; Bataille 1912; Capellano 1967; Cheype 1990; Bidaud 2009), Italy (Paccioni, Angarano 1979 after Kers 1985; Narducci, Petrucci 1995; Montecchi, Sarasini 2000), Switzerland (Groß 1974, 1975; Breitenbach, Kränzlin 1986; Peter et al. 2001), and western part of former Soviet Union (Sossin 1973). In Poland it has been found in 1923, in Karkonosze range (Sudety Mts.) (Soehner 1949) (Fig. 24). The discovery of Chamonixia in the Tatra Mts. is not surprising as the vegetation (montane spruce forests on lime stone) and climatic conditions (high mean annual precipitation) of this mountain range create a typical habitat for the growth of this species. Additionally, Chamonixia was found on the Slovak side close to Tatra Mts. (in Mała Fatra; Hagara 1985). The position of the Tatra locality above see level can, together with those in Swiss and French Alps, be regarded as one of the highest. To the contrary, the locality in Beskid Niski Mts. is one of the lowest in altitude in Central Europe similar to some German sites. Additionally, this area is geologically and climatically much different from the former Polish locality: it is built of a flysh with low or very low calcium contents and is characterized by rather mild climate but quite high humidity (Warszyńska 1996). In this respect it rather resembles localities in Czech Republic or Austria.

Although known from several countries in Europe, Chamonixia caespitosa seams to be rare and is frequently placed in the Red Lists of threatened fungi (Slovakia: Lizoň 2001; Czech Republic: Holec, Beran 2006; Poland: Wojewoda, Ławrynowicz 2006; Switzerland: Senn-Irlet et al. 2007; Germany: Benkert et al. 1992; Austria: Krisai-Greilhuber 1999; Sweden: Gärdenfors (ed.) 2005; Norway: Brandrud et al. (eds) 2006; Finland: Rassi et al. (eds) 2001). The species is known also from outside Europe (USA: Dodge, Zeller 1934; Castellano et al. 1999; Canada: Bowerman, Groves 1962; China: Eckblad, Ellingsen 1984). However, the specimens found in North America, especially western coast, perhaps represent a different species (see Kers 1985).

In Europe Chamonixia caespitosa is a mycorrhizal symbiont of spruce. Its mycorrhizae with Picea abies were described and illustrated by Raidl $(1999,2008)$. They were also detected during studies of ectomycorrhiza in spruce forests by, e.g., Peter et al. (2001) in Switzerland. In western USA the species was also reported to be connected to other Pinaceae: Abies amabilis, Tsuga spp., Pseudotsuga menziesii (Castellano et al. 1999), but probably this applies to the taxon different than European Chamonixia caespitosa (see above). In Central and Western Europe Chamonixia fruitbodies were found in spruce forests mostly in mountainous regions (Alps, Apennines, Sudety Mts., Carpathians), and the distribution of this species was described by Groß et al. (1980) as montane-subalpine. However, in Scandinavia they occur at lower altitudes in regions with climatic conditions similar to those of spruce montane forests of Central Europe (Bohlin, Jeppson 1983). The distribution of the species can thus be described as montane-subalpine-subboreal. 
Although growing mostly in the sites with rather high lime contents, Chamonixia was also found in forests developed on the neutral or even slightly acid bedrock in Sweden and Austria (Bohlin, Jeppson 1983; Kers 1985). Bohlin and Jeppson (1983) summarized ecological requirements of this species and stated that Chamonixia caespitosa occurs in regions with either high annual rainfall or at least high air humidity. Kers (1985) analyzed Scandinavian localities of Chamonixia and characterized the ecological requirements of the species precisely. He stated that the species occurs in old-growth spruce forests, mostly on slopes with northern exposition or in ravines. The localities are characterized by constant water supply, either from small streams or underground moving water, and usually by high accumulation of woody debris - decaying wood was also mentioned as a substrate of Chamonixia by, e.g., Groß (1974) and Bohlin \& Jeppson (1983). Frequently, forests, where Chamonixia occurs, are of high value also as habitats of rare and threatened plant species. The observations of Kers have been recently confirmed during inventory of Chamonixia localities in Sweden made by Bohlin $(2005,2006)$ and Vesslén and Bengtson (2008). The inventories of all known and potential localities of this species were undertaken in the frame of the national project aiming for protection of Chamonixia and its habitats - both are threatened mostly due to timber harvesting and forest practices (mostly drainage). The projects also aimed to assess the status of Chamonixia populations and evaluate the condition of habitats (Bohlin 2005; Vesslén, Bengtson 2008) and should eventually lead to developing suitable preservation measures. Very detailed descriptions of Chamonixia localities (including accompanying fungal and plant taxa) from outside Sweden can be found in, e.g., Groß (1974), Hæggström (1987), and Zureck et al. (1999). The basidiocarps of Chamonixia develop in soil, mostly under extensive moss or spruce needle cover, but they are frequently partially exposed when mature. For this reason the species was rated among semihypogeic fungi (Bohlin, Jeppson 1983).

The ontogeny of the fruitbodies of Chamonixia caespitosa has recently been investigated in detail by Clémençon (2005). He showed that in the early stages of development the later gasterocarpic fruitobodies resemble those of some other Boletales: the tubular hymenophore is formed on the primordial stem, which is then covered by the hyphae of pileus margin and stem surface. In the later stages, those hyphae (the amphicleistoblema) cover completely the hymenophore and entire fruitbody. The author concluded that development of the fruitody is exocarpic, claustropileate and amphicleistoblemate, and found similarities of some stages of this development with development of fruitbodies of Suillus and Boletinus. Clémençon pointed out that these similarities strongly support the taxonomical position of Chamonixia within Boletales.

The taxonomic position of Chamonixia was controversial for a long time. Certain similarities (mostly spore morphology) made some authors place this species in the genus Hymenogaster or in close relationship to it (e.g., Soehner 1949; Lange 1956; Szemere 1965). Another hypothesis placed Chamonixia close to Gautieria (e.g., Zeller 1948; Cribb 1958; Smith 1973), however, differences in spore print color and gasterocarp structure between both genera were soon realized (Lange, Hawker 1951; Capellano 1967). Smith and Singer (1959), found some similarities of peridium structure and spore morphology of the American species to some members of Boletales. They also realized that Chamonixia basidiocarps were parasitized by 
Sepedonium chrysospermum s.l., a typical boletophilous fungus. Similar color reaction of bruised basidiocarps and mycelium of Chamonixia and Gyroporus cyanescens was also evident. Thus, Moser (1978) and Jülich (1981) in their monographs placed Chamonixia in the family Boletaceae. The close affinity of Chamonixia caespitosa to Gyroporus cyanescens was suggested again by Bresinsky \& Wittmann-Bresinsky (1995) and Bresinsky (1996) due to the presence of pigments: gyrocyanin, chamonixin and gyroporin; the first two being responsible for blueing of the fruitbodies (Steglich et al. 1977; Bresinsky, Besl 1979). This, however, was not supported by molecular studies: Kretzer and Bruns (1999) found this species to be more related to Boletus, Chalciporus and Phylloporus than to Gyroporus, basing on the analysis of combined atp6 and mt LSU rDNA gene sequences. The molecular analysis by Binder \& Bresinsky (2002) and Binder \& Hibbet (2006) revealed, however, that the closest relative of Chamonixia is genus Leccinum (genus Leccinum was not included in the study by Kretzer \& Bruns 1999).

The morphology and anatomy of Chamonixia caespitosa ectomycorrhizae with Picea abies have been studied in detail by Raidl $(1999,2008)$. They were characterized by a ring-like hyphal arrangement of the mantle hyphae and highly differentiated rhizomorphs of type F (Agerer 1995), characteristic features of many members of Boletaceae. Clamp connections were absent. The bluish reaction of the mantle and rhizomorphs was encountered after bruising or treatment with FEA. The ectomycorrhizae of Chamonixia differed from the ectomycorrhizae of Gyroporus cyanescens, which was suggested as a close relative of Chamonixia. In Gyroporus ectomycorrhizae the reaction was not caused by simple bruising but treatment with concentrated sulfuric acid. Additionally, the hyphae of Gyroporus form clamps and the ring-like arrangement of hyphae in the mantle is absent. The bluish reaction has also been found in ectomycorrhizae of other members of Boletales, e.g., Leccinum (Müller, Agerer 1990) and Alpova diplophloeus (Miller et al. 1988; Wiedmer et al. 2001). Close anatomical similarities of Chamonixia ectomycorrhizae with Leccinum ectomycorrhizae are especially interesting as molecular studies indicate that these genera are closely related (see above). Studies of ectomycorrhizae indicate that hypogeous structures may be regarded as a reliable source of taxonomic and phylogenetic information (e.g., Agerer 1999, 2003, 2004; Eberhardt 2002; Martin, Raidl 2002; Beenken 2004; Mleczko, Ronikier 2007).

Acknowledgements. The authors wish to thank Dr. W. Paul and Dr. M. Ronikier (Institute of Botany, Polish Academy of Sciences) for the translation of Swedish and French articles on Chamonixia caespitosa and to Dr. A. Ronikier (Institute of Botany, Polish Academy of Sciences) for valuable comments on the text. Special thanks to Prof. Andreas Bresinsky (University of Regensburg) for helpful remarks and sending of a literature. 


\section{REFERENCES}

Agerer R. 1995. Anatomical characteristics of identified ectomycorrhizae: an attempt towards a natural classification. (In:) A.K. Varma, B. Hock (eds). Mycorrhiza: structure, function, molecular biology and biotechnology: 685-734. Springer, Berlin.

Agerer R. 1999. Never change a functionally successful principle: The evolution of Boletales s.l. (Hymenomycetes, Basidiomycota) as seen from below-ground features. Sendtnera 6: 5-91.

Agerer R. 2003. Systematically important characteristics of ectomycorrhizae and their correspondence with some selected fungal relationships. (In:) XIV CEM Abstracts. XIV Congress of European Mycologists, Yalta, Crimea, Ukraine, 22-27 September 2003: 65.

Agerer R. 2004. Rhizomorph structure of Hymenomycetes: A possibility to test DNA-based phylogenetic hypotheses? (In:) R. Agerer, M. Piepenbring, P. Blanz (eds). Frontiers in Basidiomycote Mycology: 249-302. IHW-Verlag, Eching.

Austrian Mycological Society 2008. Database of fungi in Austria. Edited by Dämon, W., Hausknecht, A., Krisai-Greilhuber, I. [http://www.austria.mykodata.net ] [Retrieved: May 7, 2009].

Bataille F. 1912. Miscellanées mycologiques. Bull. Soc. mycol. Fr. 28: 127-130.

Beaton G., Pegler D.N., Young T.W.K. 1985. Gasteroid Basidiomycota of Victoria State, Australia: 5-7. Kew Bulletin 40 (3): 573-598.

Beenken L. 2004. Les ectomycorrhizes du genre Russula. Bull. Soc mycol. Fr. 120 (1/4): 293-333.

Bendiksen K., Molia A. 2009. The Norwegian Mycological Database (NMD). Natural History Museum, University of Oslo, [Presented on the web by Einar Timdal] [Retrieved May 7, 2009, from the Database at: http://www.nhm.uio.no/botanisk/sopp/]

Benkert D., Dörfelt H., Hardtke H.-J., Horsch G., Kreisel H., Krieglsteiner G.J., Lüderitz M., Runge A., Schmid H., Schmitt J.A., Winterhoff W., Wöldecke K., Zehfuß H.-D., Einhellinger A., Groß G., Große-Brauckmann H., Nuss I., Wölfel G. 1992. Rote Liste der gefährdeter Großpilze in Deutschland. Deutsche Gesellchaft für Mykologie e.V. Natur schutzbund Deutschland e.V. (NABU) Eching.

Bidaud A. 2009. Taxons rares ètudiès en 2006: 3e partie. Bull. mycol. bot. Dauphiné-Savoie 193: 49-63.

Binder M., Bresinsky A. 2002. Derivation of a polymorphic lineage of Gasteromycetes from boletoid ancestors. Mycologia 94: 85-98.

Binder M., Hibbet D.S. 2006. Molecular systematics and biological diversification of Boletales. Mycologia 98 (6): 971-981.

Bohlin A. Bohlin K. 2005. Inventering av Blåtryffel Västra Götalands län 2004. Rapport 2005: 17. Länsstyrelsen i Västra Götalands län.

Bohlin K. 2005. Åtgärdsprogram för bevarande av blåtryffel (Chamonixa caespitosa). Rapport 5472, May 2005. Naturvårdsverket.

Bohlin K. 2006. Nya fynd av blåtryffel (Chamonixia caespitosa). Svensk Mykol. Tidskr. 27 (3): 22-25.

Bohlin K., Jeppson M. 1983. Frågor kring blåtryffeln, Chamonixia caespitosa - Chamonixia caespitosa found in Sweden. Svensk Bot. Tidskr. 77: 293-300.

Bowerman C.A., Groves J. W. 1962. Notes on fungi from northern Canada. Can. J. Bot. 40 (1): 239-254.

Brandrud T.E., Bendiksen E., Hellik Hofton T., Høiland K., Jordal J.B. 2006. Sopp. Fungi. (In:) J.A. Kålås, Å. Viken, T. Bakken (eds). Norsk Rødliste 2006: 103-128. Artsdatabanken, Trondheim, Norway.

Breitenbach J., Kränzlin F. 1986. Pilze der Schweiz. Band 2. Heterobasidiomycetes (Gallertpilze), Aphyllophorales (Nichtblätterpilze), Gasteromycetes (Bauchpilze). Verlag Mycologia, Luzern.

Bresinsky A. 1996. Abstammung, Phylogenie und Verwandtschaft im Pilzreich. Z. Mykol. 62 (2): 147168.

Bresinsky A., Besl H. 1979. Notizen über Vorkommen und systematische Bewertung von Pigmenten in Höheren Pilzen (3). Untersuchungen an Boletales aus Amerika. Z. Mykol. 45 (2): 247-264.

Bresinsky A., Wittmann-Bresinsky B. 1995. Ploidy levels and evolution in Boletales. Sydowia Beih. 10: 35-47.

Capellano A. 1967. Une espèce rare de Gastéromycète hypogé: Chamonixia caespitosa Rolland. Bull. Soc. mycol. France 83: 218-224.

Castellano M.A., Smith J.E., O’Dell T., Cazares E., Nugent S. 1999. Handbook to Strategy 1 Fungal Species in the Northwest Forest Plan. U.S. Department of Agriculture, Forest Service, Pacific Northwest Research Station, Portland, OR, General Technical Report PNW-GTR-476.

Chang Y.S., Kantvilas G. 1993. A catalogue of Leonard Rodway's collection of fungi. I. Hymenomycetes and Gasteromycetes. Tasmanian Herb. Occas. Publ. 4: 1-52. 
Cheype J.L. 1990. Chamonixia caespitosa Rolland, une nouvelle station pour la Haute-Savoie. Bull. Féd. mycol. Dauphiné-Savoie 119: 31.

Clémençon H. 2005. New observations on the basidiome ontogeny of Chamonixia caespitosa (sequestrate Boletaceae). Persoonia 18 (4): 499-504.

Corner E.J.H., Hawker L.E. 1953. Hypogeous fungi from Malaya. Trans. Br. Mycol. Soc. 36 (2): 125137.

Cribb J.W. 1958. The Gasteromycetes of Queensland IV. Gautieria, Hysterangium and Gymnoglossum. Pap. Univ. Queensl., Dept. Bot. 3: 153-159.

Dodge C.W., Zeller S.M. 1934. Hymenogaster and related genera. Ann. Missouri Bot. Garden 21: 625708 .

Eberhardt U. 2002. Molecular kinship analyses of the agaricoid Russulaceae: correspondence with mycorrhizal anatomy and sporocarp features in the genus Russula. Mycol. Progress 1 (2): 201-223.

Eckblad F.E., Ellingsen H.J. 1984. Gasteromycetes from China collected by Dr. Harry Smith 1921-1923, 1924-1925 and 1934. Sydowia 37: 29-42.

Gärdenfors U. (ed.). 2005. Rödlistade arter i Sverige 2005. (The 2005 redlist of swedish species). ArtDatabanken, Uppsala, Sweden.

Groß G. 1974. Über einige neuere Chamonixiafunde in Mitteleuropa. Z. Pilzk. 39: 203-212.

Groß G. 1975. Ergänzungen zu „Über einige neuere Chamonixiafunde...“. Z. Pilzk. 41: 199-200.

Groß G., Runge A., Winterhoff W. 1980. Bauchpilze (Gasteromycetes s.l.) in der Bundesrepublik Deutschland und Westberlin. Beih. Z. Myk. 2: 1-220.

Hæggström C.-A. 1987. Chamonixia caespitosa found in Finland. Memor. Soc. Fauna Flora Fenn. 63 (3): 97-100.

Hagara L. 1985. Chamonixia caespitosa Rolland na Slovensku - Chamonixia caespitosa Rolland in der Slowakei. Česká Mykol. 39 (1): 51.

Holec J., Beran M. (eds). 2006. Červený seznam hub (makromycetů) České republiky. Red list of fungi (mycromycetes) of the Czech Republic. Příroda, Praha, 24: 1-280. [http://www.natur.cuni.cz/cvsm/].

Jülich W. 1981. Die Nichtblätterpilze, Gallertpilze und Bauchpilze. Kleine Kryptogamenflora Band IIb/1. Gustav Fischer Verlag, Jena.

Kers L.E. 1985. Hur man finner och känner igen blåtryffeln, Chamonixia caespitosa - How to find and identify Chamonixia caespitosa. Svensk Bot. Tidskr. 79: 25-32.

Kotlaba F. 1971. Šamonie modrající - Chamonixia caespitosa Rolland, nová vzácná břichatkovitá houba v Československu - Chamonixia caespitosa Rolland, a rare gasteromycetous fungus new for Czechoslovakia. Česká Mykol. 25 (1): 43-46.

Kretzer A.M., Bruns D.T. 1999. Use of atp6 in fungal phylogenetics: an example from the Boletales. Mol. Phyl. Evol. 13: 483-492.

Krisai-Greilhuber I. 1999. 5. Pilze. Rote Liste gefährdeter Großpilze Österreichs, 2 Fassung. (In:) H. Nikfeld (ed.). Rote Liste gefährdeter Pflanzen Österreichs, 2nd edn.: 229-266.

Label T. 2006. Weird sisters - affinities of some Australian truffle-like fungi. (In:) $8^{\text {th }}$ International Mycological Congress, 21-25 August 2006, Cairns Convension Centre, Queensland, Australia. Congress Handbook \& Abstract Book 1. Abstract PS1-66-03443.

Lange M. 1956. Danish Hypogeous Macromycetes. Dansk Bot. Arkiv 16: 1-84.

Lange M., Hawker L.E. 1951. Some hypogeal gasteromycetes from Jämtland, Sweden, and adjacent districts of Norway. Svensk Bot. Tidskr. 45 (4): 591-596.

Lizoň 2001. Červený zoznam húb Slovenska. 3. (December 2001). (In:) D. Balaž, K. Marhold, P. Urban (eds). Červeny zoznam rastlin a živočichov Slovenska. Ochr. Prir. 20 (Suppl.): 6-13.

Mader K., Mader A. 1975. Chamonixia caespitosa Roll. Entwicklungsstudien. Z. Pilzk. 41: 175-180.

Martin M.P., Raidl S. 2002. The taxonomic position of Rhizopogon melanogastroides (Boletales). Mycotaxon 84: 221-228.

Miller S.L., Koo C.D., Molina R. 1988. An oxidative blue-bruising reaction in Alpova diplophloeus (Basidiomycetes, Rhizopogonaceae) + Alnus rubra ectomycorrhizae. Mycologia 80 (4): 576-581.

Mleczko P., Ronikier M. 2007. Features of ectomycorrhizae confirm molecular phylogenetics of Suillus (Boletales) rather than carpophore-based systematics: insights from studies on Suillus variegatus, $S$. plorans and related species. Nova Hedw. 84 (1/2): 1-20.

Montecchi A., Sarasini M. 2000. Funghi ipogei d’Europa. A.M.B. Fondazione, Centro Studi Micologici, Trento-Vicenza. 
Moser M.M. 1978. Die Röhrlinge und Blätterpilze. Kleine Kryptogamenflora, Band IIb/2. Gustav Fischer Verlag, Stuttgart.

Müller W., Agerer R. 1990. Studien an Ektomykorrhizen XXIX. Drei Ektomykorrhizen aus der Leccinum scabrum-Gruppe. Nova Hedw. 51 (3/4): 381-410.

Narducci R., Petrucci P. 1995. Macromiceti reperiti in provincia di Lucca negli anni 1985-1994 con le indicazioni dei luoghi e degli ambienti di raccolta. (In:) "Contributo alla conoscenza dei macromiceti che crescono nella provincia di Lucca. Il decennio 1985-1994”: 3-74. Comunità Montana della Garfagnana, Orto Botanico "Pania di Corfino".

Peter M., Ayer F., Honegger R. 2001. Above- and belowground community structure of ectomycorrhizal fungi in three Norway spruce (Picea abies) stands in Switzerland. Can. J. Bot. 79 (10): 1134-1151.

Raidl S. 1999. Chamonixia caespitosa Rolland + Picea abies (L.) Karst. Descr. Ectomyc. 4: 1-6.

Raidl S. 2008. Chamonixia caespitosa. (In:) R. Agerer (ed.). Colour Atlas of Ectomycorrhizae, plate 196. Einhorn-Verlag+Druck GmbH, Schwäbisch Gmünd.

Rassi P., Alanen A., Kanerva T., Mannerkoski I. (eds). 2001. The Red List of Finnish Species. Ministry of the Environment \& Finnish Environment Institute, Helsinki.

Rolland M.L. 1899. Excursion à Chamonix - Été et automne de 1898. Bull. Soc. mycol. Fr. 15: 73-78.

Senn-Irlet B., Bier G., Egli S. 2007. Rote Liste Grosspilze. Rote Liste der gefährdeten Arten der Schweiz, Ausgabe 2007. Bundesamt für Umwelt (BAFU), Bern Eidgenössische Anstalt für Wald, Schnee und Landschaft (WSL), Birmensdorf ZH.

Smith A.H. 1973. Agaricales and related secotioid Gasteromycetes. (In:) G.C. Ainsworth, A.S. Sussman (eds). The Fungi. An advanced treatise. Vol. IVB: 421-450. Academic Press, New York.

Smith A.H., Singer R. 1959. Studies in secotiaceous fungi. IV. Gastroboletus, Truncocolumella and Chamonixia. Brittonia 11: 205-223.

Soehner E. 1922. Hymenogaster coerulescens (spec. nov.). Z. Pilzk. 1: 6-8.

Soehner E. 1949. Deutsche Hydnangiaceae. Z. Pilzk. 15: 11-20.

Sossin, P.E. 1973. Opredelitel' gasteromitsetov SSSR. Akademija Nauk SSSR, Leningrad.

Steglich W., Thilmann A., Besl H., Bresinsky A. 1977. Pilzpigmente, 29. 2.5-Diarylcyclopentan-1.3-dione aus Chamonixia caespitosa (Basidiomycetes). Z. Naturforsch. 32c: 46-48.

Szemere L. 1965. Die unterirdischen Pilze des Karpatenbeckens. Akadémiai Kiadó, Budapest.

Verbreitungsatlas der Pilze der Schweiz. [http://www.wsl.ch/dossiers/pilze/swissfungi/verbreitungsatlas/ index_DE] [Retrieved: May 7, 2007].

Vesslén G., Bengtson J. 2008. Inventering av blåtryffel (Chamonixia caespitosa) i Gävleborgs län 2008. Inventeringen har utförts av Länsstyrelsen i Gävleborgs län inom ramen för Åtgärdsprogram för bevarande av blåtryffel (Chamonixia caespitosa). Länsstyrelsen Gävleborg.

Warszyńska J. (ed.). 1996. Karpaty polskie. Przyroda, człowiek, działalność. Wydawnictwo Uniwersytetu Jagiellońskiego, Kraków.

Wiedmer E., Senn-Irlet B., Agerer R. 2001. Alpova diplophloeus (Zeller \& Dodge) Trappe \& A.H. Smith + Alnus viridis (Chaix) DC. Descr Ectomyc. 5: 1-8.

Wojewoda W., Ławrynowicz M. 2006. Red list of the macrofungi in Poland. (In:) Z. Mirek, K. Zarzycki, W. Wojewoda, Z. Szeląg (eds). Red list of plants and fungi in Poland: 53-70 W. Szafer Institute of Botany, Polish Academy of Sciences, Kraków.

Zeller S.M. 1948. Notes on certain Gasteromycetes, including two new orders. Mycologia 60: 639-668.

Zhang B.C., Yu Y.N. 1989. Chamonixia bispora sp. nov. (Boletales) from China. Mycotaxon 35 (2): 277281.

Zureck A., Hassmann K., Conrad U., Conrad R. 1999. Neufunde der Blaunuß, Chamonixia caespitosa Rolland, in Thüringen. Boletus 23 (1): 1-6. 
Nowe stanowiska Chamonixia ceaspitosa (podziemne Boletaceae) w Europie Środkowej

\section{Streszczenie}

Chamonixia caespitosa Rolland, do niedawna znana była w Polsce jedynie ze stanowiska odkrytego w 1922 roku w Sudetach. W latach 2008 i 2009 odnalezione zostały dwa kolejne stanowiska tego rzadkiego gatunku: w górnoreglowym borze świerkowym na wysokości $1540 \mathrm{~m}$ n.p.m w Tatrach, oraz lesie mieszanym z udziałem świerka w Beskidzie Niskim, na wysokości ok. 400 m n.p.m. Cechy makro- i mikroskopowe znalezionych owocników odpowiadają opisom podawanym w literaturze z innych stanowisk w Europie Środkowej. Okrągławe do nieregularnie bulwkowatych owocniki charakteryzuje szybkie niebieskie przebarwianie się perydium po uszkodzeniu, obecność kolumelli oraz brązowawej, gąbczastej gleby. Podstawki wykształcają najczęściej 4 brązowawe zarodniki pokryte urzeźbieniem w postaci podłużnie przebiegających żeber. Artykuł podsumowuje dotychczasowe informacje na temat taksonomii, ekologii i chorologii Chamonixia caespitosa, ontogenezy owocników oraz cech jej ektomikoryz. 

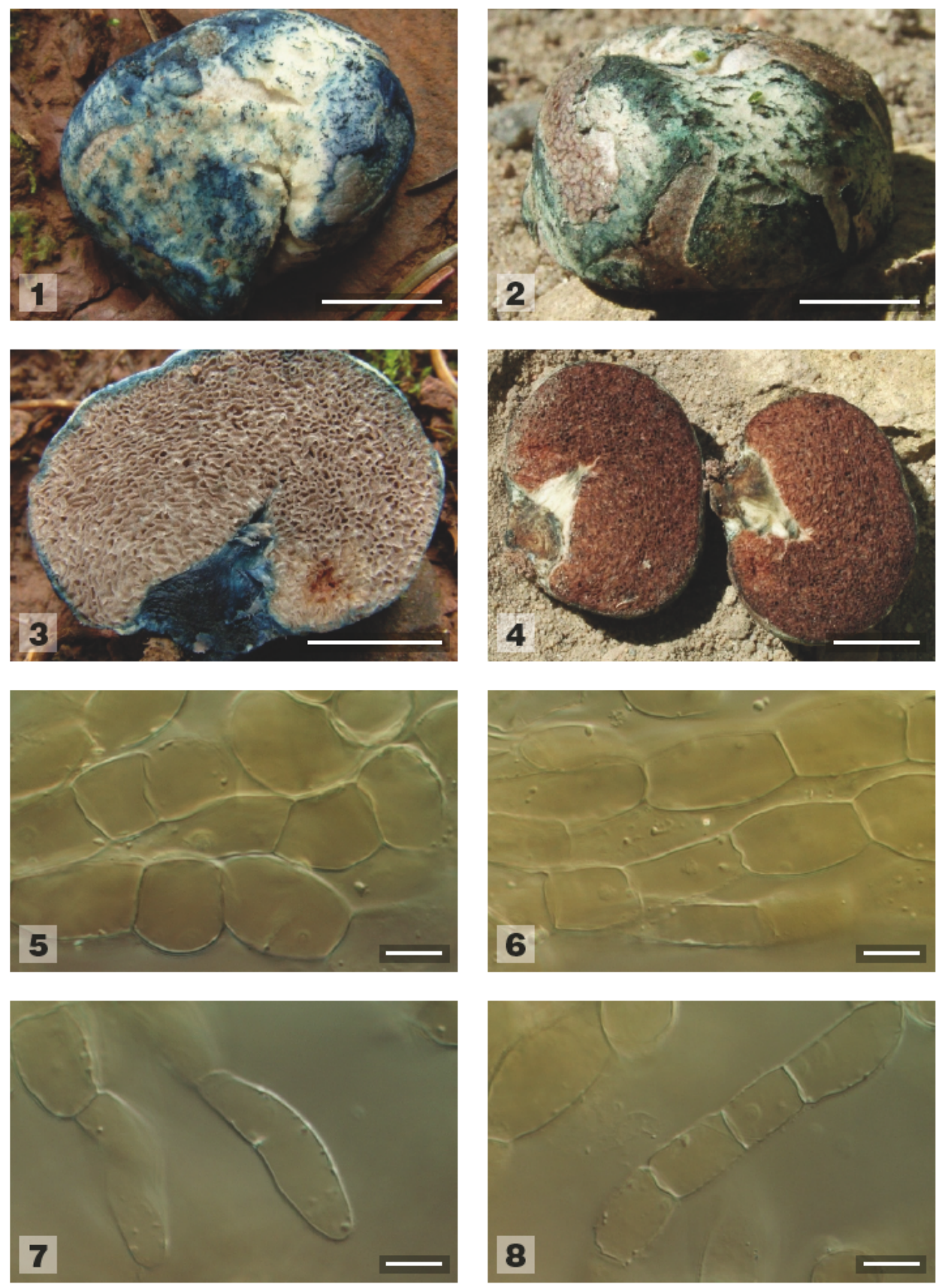

Figs 1-8. Chamonixia caespitosa. 1. Fruitbody short time after exposal to the air, with characteristic, strong blue color reaction. 2. The same fruitbody as in Fig.1 after few hours; the blue coloration changed to olive-greenish. 3. Cross section of the fresh fruitbody; gleba and short columella visible. 4. Cross section of the fruitbody after some hours. 5-6. Outer layer of peridium in section; note densely septated hyphae with inflated hyphal cells. 7-8. Free hyphae on the peridium surface. Scale bars for Figs 1-4: $1 \mathrm{~cm}$, for Figs 5-8: $10 \mu \mathrm{m}$. 

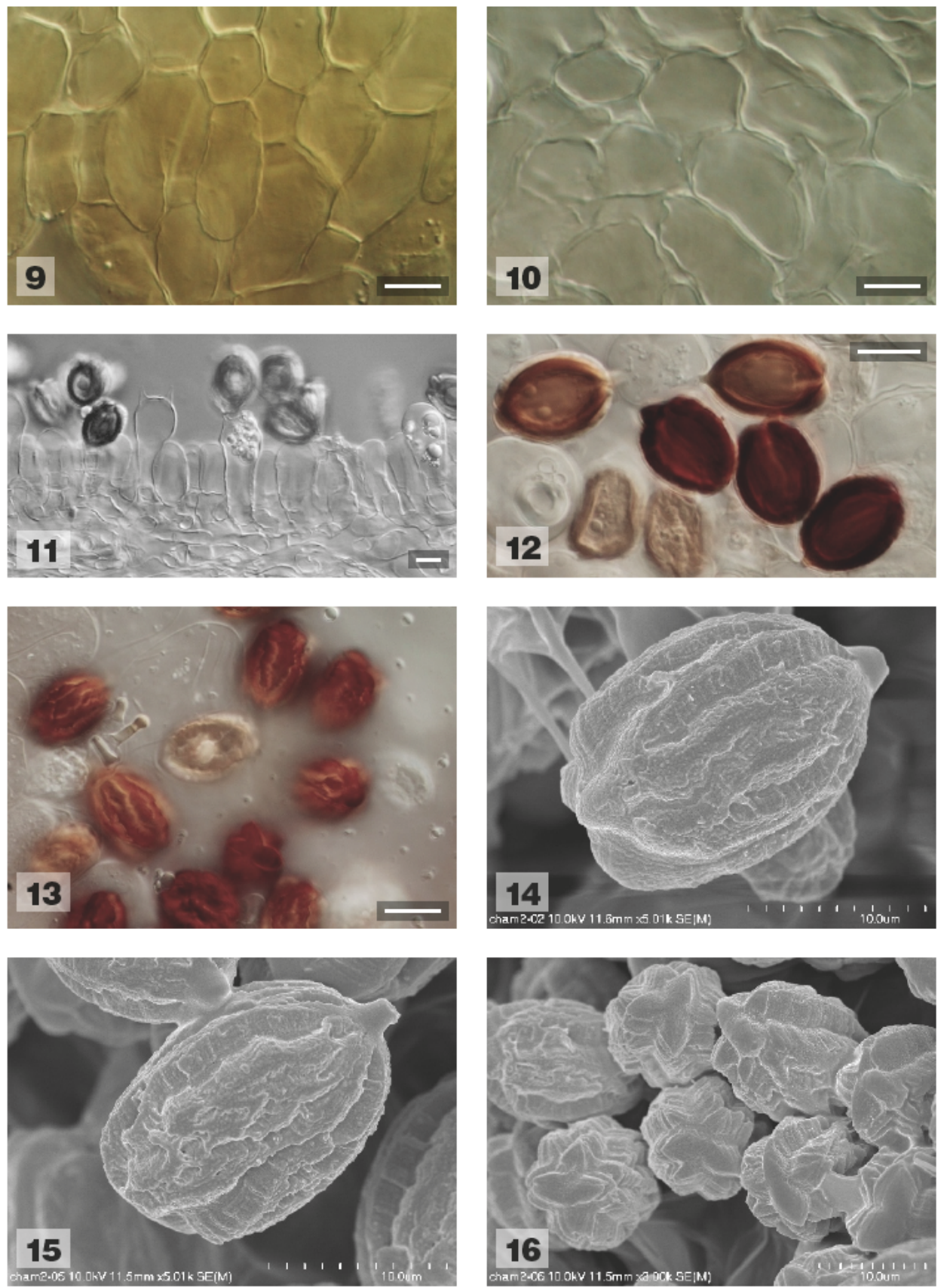

Figs 9-16. Chamonixia caespitosa. 9. Section of the peridium with hyphal ends arranged in parallel. 10. Inner layer of the peridium in section, with pseudoparenchymatic structure. 11. Section through hymenium and subhymenium. 12-13. Spores as seen in light microscope (NIC). 14-15. Spores in lateral view as seen in scanning electron microscope (SEM); note irregularely developed ornamentation in Fig. 15. 16. Spores in apical view (opposite to apiculus) as seen in scanning electron microscope (SEM); note star-like ornamentation. Scale bars for Figs 9-13: $10 \mu \mathrm{m}$. 